\title{
Toledot Yeshu (»The Life Story of Jesus«) Revisited
}

\author{
A Princeton Conference \\ Ed. by Peter Schäfer, Michael Meerson and Yaacov Deutsch
}

[Toledot Yeshu (»Die Lebensgeschichte Jesu«). Eine Konferenz in Princeton.]

Veröffentlicht auf Englisch.

Toledot Yeshu (»Die Lebensgeschichte Jesu«) ist eine polemische jüdische Gegenerzählung gegen das Neue Testament. Der

Toledot Yeshu

("The Life Story of Jesus") Revisited

Edited by

PETER SCHÄFER

MICHAEL MEERSON

YAACOV DEUTSCH

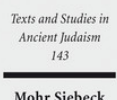

Mohr Siebeck

2011. VII, 316 Seiten. TSAJ 143

ISBN 978-3-16-151771-6

DOI 10.1628/978-3-16-151771-6

eBook PDF $114,00 €$

ISBN 978-3-16-150948-3

Leinen $114,00 €$ schließlich einen unehrenhaften Tod zu. In Vorbereitung einer wissenschaftlichen Edition und Übersetzung der Erzählung organisierten Peter Schäfer, Michael Meerson und Yaacov Deutsch eine internationale Konferenz in Princeton, die den gegenwärtigen Stand der Erforschung des polemischen Traktats diskutierte. Nachdem er lange Gegenstand heftiger und bitterer Auseinandersetzungen zwischen Christen und Juden war, ist jetzt die Zeit reif für eine nüchterne und sachliche historische Einordnung.

Inhaltsübersicht

Peter Schäfer: Introduction - Michael Sokoloff: The Date and Provenance of the Aramaic Toledot Yeshu on the Basis of Aramaic Dialectology - Peter Schäfer: Agobard's and Amulo's Toledot Yeshu - William Horbury: The Strasbourg Text of the Toledot - Adina M. Yoffie: Observations on the Huldreich Manuscripts of the Toledot Yeshu - Michael Stanislawski : A Preliminary Study of a Yiddish »Life of Jesus« (Toledot Yeshu ): JTS Ms. 2211 - Pierluigi Piovanelli : The Toledot Yeshu and Christian Apocryphal Literature: The Formative Years - Eli Yassif: Toledot Yeshu: Folk-Narrative as Polemics and Self Criticism - Philip Alexander: The Toledot Yeshu in the Context of Jewish-Muslim Debate - Sarit Kattan Gribetz: Hanged and Crucified: The Book of Esther and Toledot Yeshu - Michael Meerson: Meaningful Nonsense: A Study of Details in Toledot Yeshu - Ora Limor and Israel Jacob Yuval: Judas Iscariot: Revealer of the Hidden Truth - John Gager: Simon Peter, Founder of Christianity or Saviour of Israel? - Galit Hasan-Rokem : Polymorphic Helena - Toledot Yeshu as a Palimpsest of Religious Narratives and Identities - Yaacov Deutsch: The Second Life of the Life of Jesus: Christian Reception of Toledot Yeshu - Paola Tartakoff: The Toledot Yeshu and Jewish-Christian Conflict in the Medieval Crown of Aragon.

Yaacov Deutsch Born 1966; PhD Hebrew University, Jerusalem; currently head of the history department at David Yellin College, Jerusalem, and adjunct lecturer at the Hebrew University.

Michael Meerson Born 1973; 2006 PhD Bar-Ilan University; since 2004 Senior Researcher at Princeton University, working on Sefer Hasidim and Toledot Yeshu.

Peter Schäfer Geboren 1943; 1968 Promotion; 1973 Habilitation; 1983-2008 Professor für Judaistik an der Freien Universität Berlin; 1998-2013 Ronald O. Perelman Professor of Jewish Studies und Professor of Religion an der Princeton University; 2014-2019 Direktor des Jüdischen Museums Berlin.

Jetzt bestellen:

https://mohrsiebeck.com/buch/toledot-yeshu-the-life-story-of-jesus-revisited-9783161517716?no_cache=1 order@mohrsiebeck.com

Telefon: $+49(0) 7071-923-17$

Telefax: +49 (0)7071-51104

Mohr Siebeck GmbH \& Co. KG

Postfach 2040

D-72010 Tübingen

info@mohrsiebeck.com

www.mohrsiebeck.com 